\title{
The Effect of Accounting Record Keeping Practices on Financial Performance: Special Reference to Small and Medium Enterprises in Anuradhapura District
}

\author{
Somathilake $\mathrm{HMDN}^{1}$ \& Ranathunga KGKD ${ }^{2}$ \\ ${ }^{1,2}$ Department of Accountancy \& Finance, Faculty of Management Studies, Rajarata University of Sri Lanka
}

\begin{abstract}
In Sri Lankan context Small and Medium Enterprises (SMEs) play a vital role and contribute in significantly to the economic growth and social development through job creation, poverty alleviation and new business development, but on the other hand there are many failures of SMEs due to poor record keeping practices, inaccurate accounting information, reason to inaccurate financial performance and to make poor financial decisions. Therefore, many of SMEs die off soon after their establishments and face financial and management challenges. The purpose of this study is to identify the effect of accounting record keeping practices on financial performance of SMEs in Anuradhapura district. Preparing accounting records (PAR), preparing financial statements (PFS), computer utilization (CU) and respondents' perception (RP) used as independent variables to measure the accounting record keeping practices. Financial performance (FP) was used as the dependent variable of this study. The research was based on the quantitative research method and the data were collected from 152 SMEs in Anuradhapura district using a structured. Descriptive analysis, correlation analysis and multiple regression analysis used to analyze collected data according to SPSS 25 version. Results revealed that accounting record keeping practices show a positive effect on financial performance of SMEs and preparing financial statements have a significant effect on SMEs financial performance. So, SMEs should highly concern about record keeping practices as one of the tool to improve and increase the financial performance and relevant authorities should develop specific guidelines and must provide templates of account record keeping practices for SMEs to make them very easier and familiar with account practices.
\end{abstract}

Keywords: Accounting Record Keeping, Anuradhapura District, Financial Performance, Financial Statements, Small and Medium Enterprises

\section{INTRODUCTION}

$\mathrm{S}$ MEs play an important role in economic development through different ways such as creating employment opportunities, training of workers and entrepreneurs, poverty alleviation, income distribution and regional development and so on. Therefore, SME sector can be seen as a core segment of economic development in the country. SME's contribution to the total GDP of the country has increased to $52 \%$ in 2011 from $40 \%$ in 2010. Of the 30,000 registered SMEs in the country, approximately $75 \%$ are based outside the Western province, with rural SMEs contributing as much as $12 \%$ to the country's GDP, of which $78 \%$ is for agriculture GDP, apart from providing $36 \%$ of industrial development. Despite such importance to the economy, access to finance is one of the biggest challenge SMEs face, and due to this, they have difficulty to sustaining the business resulting in more than $40 \%$ of SMEs are ceasing to exist within ten years of operation. Main reason why SMEs do not have easy access to formal finance is due to the lack of formality in running the business and the indiscipline in financial record keeping which leads to financial institutions not having confidence and not being able to rely on these SMEs to provide them with reliable information whether they are financial statements or business data, (CA Sri Lanka, 2014). However, evidence has been found that there are many failures of SMEs in Sri Lanka such as inadequate capital, inadequate institutional credit facilities, Use of outdated technology, improper accounting techniques, inadequate sales and carelessness of small businesses are main problems faced by the Sri Lankan SME sector. Meanwhile SMEs fail to produce reliable financial statements, because most of them maintain financial records in a very informal manner. As a result of these SMEs often face accounting and financial management challenges since poor record keeping, inefficient use of accounting information in financial decision making. Proper accounting is most important in making sound economic decisions, (Amoako, 2013). In business management, past research has shown that proper records of all business transactions are essential to the success of the business. Therefore keeping of proper records and writing of financial statements have great benefits for SMEs. They are important management tools because they provide an accurate reflection of financial performance of the business, Muchira (2012). According to Bandara \& Rathnasiri (2016) they explained that the rate of business failure among SMEs is 45 percent in Sri Lanka and seven variables are significant in explaining business failure such as business planning, record keeping, issuing postdated cheques, budgetary controls, staff quality, basis of recruitment and commitment for business management. It shows that these variables fall into few broader areas of business such as lack of prior business planning, lack of up to date reliable accounting data, inappropriate financial and human capital management, and inadequate commitment of owners for business management. An effectiveness in financial management and live recording of accounting data are basis of good foundation for business success. Central Bank of Sri 
Lanka (1998) has been found that SMEs have to face many difficulties due to inadequate capital, use of outdated technology, inadequate institutional credit facilities, inadequate knowledge, improper accounting techniques and inattentiveness of small businesses. Unfortunately, most of SMEs lack of funding from bank and other financial institutions because this sector is like to be a high risk investment area due to there is bad accounting practices. And also the SME sector fails to produce proper financial reports for better assessment, Emmanuel et al (2014). According to Eloho (2016) stated that the misuse, Poor and inaccurate record keeping of account information to misjudge the financial condition of SMEs and make poor financial decisions. Because of these issues SMEs have to face many difficulties to succeed and raise funds or borrowings. At worst, this sector could eventually face failure and bankruptcy. Therefore, this research focuses on accounting record keeping practices and its effect on financial performance of SMEs in Sri Lanka.

\section{OBJECTIVES OF THE STUDY}

\section{Main Objectives}

- To investigate the effect of accounting record keeping practices on financial performance of SMEs.

\section{Sub Objectives}

- To examine the effect of preparing accounting records on financial performance of SMEs.

- To examine the effect of preparing financial statements on financial performance of SMEs.

- To examine the effect of computer utilization on financial performance of SMEs.

- To examine the effect of respondents' perception on financial performance of SMEs.

\section{EMPIRICAL REVIEW}

\section{Preparing Accounting Records and Financial Performance}

Good records provide the financial data that help the business operate more efficiently, thus increasing the profitability. Accurate and complete records allow the business manager and accountant to identify all business assets, liabilities, income and expenses. That information helps to identify both the strong and weak phases of the business operations. Nelson and Onias (2011) concluded that keeping accurate accounting records creates a profitable business. Madurapperuma et al (2016) found that SMEs keep complete set of accounts to capture sales and cost of sales and results confirmed that preparing accounting records positively influence on the performance of SMEs. However, few numbers of SMEs are keeping primary entries to record information. Some small and medium-sized entrepreneurs have kept primary entries to record information. Muchira (2012) investigated extent to which the owners or managers of Micro and Small Enterprises keep records in their businesses, focusing on 84 SMEs. Findings revealed that, some of the Medium Sized Enterprise owners/managers kept various records which included the purchase day or order records, the receipt book, the expenditure or bills book, the payroll records and the assets register. Further investigation revealed that the MSEs do not keep complete accounting records because of lack of accounting knowledge and the cost of hiring professional accountants. As a result, there is inefficient use of accounting information to support financial performance measurement by SMEs. This made it difficult for the entrepreneurs to calculate their business profit efficiently. Majority of SMEs do not keep proper records of their businesses, hence, inability to measure financial performance and position of their businesses. SMEs operators are keeping improper records like note books, writing on walls and papers. Only few of SMEs are keeping proper records such as cash book, sales day book, petty cash book, purchase day book, income statement and statement of financial position, Dawuda and Azeko (2015). Also they confirmed that SMEs owners are ignorant of the value of keeping proper financial records and have perception that it is waste of time and resources to Establishment of a Department of Finance and Accounting with qualified staff taking into account. Further they emphasized lack of education and high cost of hiring qualified staff made it very difficult for the owners to keep proper books of accounts. Some also failed to keep proper books of accounts in order to avoid tax. According to Maseko and Manyani (2011) found that there was a positive relationship between the preparation of accounting records and the financial performance of SMEs. Raymond et al (2014) researched on contributions of accounting records in efficient performance of SMEs. They revealed that some SMEs may not be able to adopt elaborate systems of accounting, a number of small scale business kept no records pertaining to their financial operations, finance, etc while some employed professional accountants to keep proper accounting records of their business. The accounting records keeping contribute to the performance of SMEs. But, SMEs do not keep proper accounting records of their activities. This study also revealed that accounting records keeping contributes significantly to the performance of SMEs and if proper records are kept, they will facilitate efficient, proper timely decision making and enhance performance in small business. According to Amoako (2013), he investigated the record keeping strategies utilized by SMEs in Kumasi (Ghana) through data based on responses to a structured questionnaire from 210 SMEs in Kumasi. The results revealed that SMEs do not maintain proper books of accounts because owners do not appreciate the need to keep accounting records, lack the necessary accounting knowledge and blame the cost of hiring accounting professional. Consequently, the application of accounting information to support assessment of financial performance by SMEs in Ghana is inefficient. Rahamon and Adejare (2014) investigated the impact of Accounting Records Keeping on the Performance of the Small Scale Enterprises and data collected were analyzed using both the qualitative and quantitative methods. Findings revealed that majority of the respondents keep business accounting records. Records are kept on cash basis. Sales purchases, 
creditors and debtors, receipts, invoices, payment vouchers are used as record keeping documents which help to reduce operating costs and improve efficiency and productivity. Further they revealed that, there is a strong positive relationship between accounting record keeping and performance of small scale enterprises. This implies that accounting record keeping affects performance of small scale enterprises. Based on above literature, First hypothesis developed as,

H1: There is a significant effect of preparing accounting records on financial performance of SMEs.

\section{Preparing Financial Statements and Financial Performance}

Financial statements refers to formal and original statements which are prepared to disclose financial health in the terms of profits, position, and prospects as on a certain data. According to Rathnasiri (2014) book keeping alone without preparing reports is likely not to be fundamental in aiding decision making unless proper reports are prepared and analyzed to attach a meaning so as to an help decision makers. Madurapperuma et al (2016), concluded that most SMEs do not prepare a complete set of financial statements. An organization may fail to prepare financial statements, even with well-maintained account books, as accounting knowledge/skills are required to prepare financial statements. Financial statements provide the most basic and important information in decision making. Good financial decisions are predicted based on the ability to trust reliable financial information and financial statements. Inefficient decisions can lead to poor financial management and ultimately lead to misery / failure. Efficient use of financial statements in decision making can improve financial management and keep the company viable. According to Auken \& Carrahe (2013) that it is a prerequisite for making financially sound decisions, even with reliable information. Madurapperuma et al (2016) found that there was a positive relationship between preparing financial statements and financial performance based on target population comprised of 100 registered SMEs in Gampaha district in Sri Lanka. They further stated that, when business grows the need to prepare complete set of financial statements increases, especially into medium size. It is at a medium size that the business financial performance reporting will open not only to internal users but also to external users like lenders. According to Amoako et al (2014), they concluded that the income statement is the mostly prepared financial report of SMEs. Some of SMEs prepare statements on incomes, statement of cash flow, statement of change in equity and statement of financial position. Some of the enterprises however do not keep any records of their business transactions and they do not prepare the accounting statements. As a result, there is inefficient use of accounting information to support financial performance measurement by SMEs. This made it difficult for the entrepreneurs to calculate their business profit efficiently, Muchira (2012). According to Maseko and Manyani (2011) investigated accounting record keeping practices for performance measurement employed by SMEs in Zimbabwe by using target population comprised of 100 SMEs. The results confirmed that most SMEs do not prepare a complete set of financial statements with some not preparing any financial statement at all. This is supported by only 27 percent of SMEs preparing financial statements to report financial performance. An entity may fail to prepare financial statements even with well-maintained books of accounts because the preparation of financial statements requires accounting skills. According to Karunanda and Jayamaha (2011) concluded that there is significant positive correlation between the financial statement analysis practices and financial performance of SMEs. Therefore, the SMEs who are analyzing financial statements are performing well than those who do not. Therefore these studies show that SMEs do not prepare financial statement even they maintain accounting records. Because of that preparation of financial statement require accounting knowledge and skills. As a result of those SMEs owners cannot perform financial analysis and take proper decision to establish trends to know whether their businesses are doing well or not. Therefore it was found that there was a positive relationship between the preparing financial statement and financial performance. Based on above literature, Second hypothesis developed as,

$\mathrm{H} 2$ : There is a significant effect of preparing financial statements on financial performance of SMEs.

\section{Computer Utilization and Financial Performance}

Studies revealed that though technology is developed fast, most of SMEs don't adopt to use ICT for accounting related activities. They used old method such as note books, writing on walls and papers to record accounting information. Therefore record keeping is not attractive and they think it is a costly and time consuming task. There are various accounting packages and computer software (Excel) can be used for accounting related activities such as Quick book, Sage, MYOB etc. Madurapperuma et al (2016) found that 73 percent of the SMEs don't use Information Technology (IT) for keeping accounting records. 44 percent of the respondents keep manual records and 29 percent don't keep any of the records. Also 15 percent of SMEs use excels and 12 percent use an accounting package for keeping accounting records. They further concluded that record keeping using ICT in SMEs is therefore not being done for the purpose of capturing accounting information for performance measurement. But, few SMEs use ICT for accounting information for security and control. This is supported by only 27 percent of SMEs preparing financial statements using ICT to report financial performance. Further they, concluded that there is a positive correlation between computer Utilization and financial performance. Rathnasiri (2014) investigated computer utilization of SMEs in financial management practices and found that SMEs widely utilize the computers in order to record their day today business transactions, preparation of financial statements and management reports and cash flow management activities representing more than 70 percent. But, SMEs do not maintain sophisticated accounting systems and 
software in accounting, they utilize computers for whatever they do relateing to accounting. Jennifer and Dennis (2015) researched on Financial Management Practices on growth of SMEs. Primary data was collected from 41 SMEs using a questionnaire administered to the business owner/manager of the SMEs. They emphasized that failure to use computers and computer assisted software among SMEs makes timely financial reporting as well as decision making very difficult. Also they concluded innovation is a key to the growth of SMEs and effort should be made to ensure SMEs are in vanguard of innovation for them to be competitive through enhancement of financial management practices through ICT. The ever changing needs of customers once met will enhance customer retention and sustainable growth rate. Based on above literature, third hypothesis was developed as,

H3: There is a significant effect of computer utilization on financial performance of SMEs.

\section{Respondents' Perception and Financial Performance}

While most of SMEs don't maintain accounting records, there are some factors that motivate others to maintain accounting records. According to Amoako (2013) they are 30 taxation purpose, income distribution purpose, performance evaluation purpose, tracking of receivables and payables, for support in accessing credit/finance and to determine the size of business. According to the research done by Rathnasiri (2014) demonstrated that majority of Sri Lankan SMEs prepare accounting records with the intention to meet the day today operative requirements. . Thus, many SMEs do not adopt the proper format of financial statement preparation as they have no intention of fulfilling statutory obligations. But poorly prepared accounting information makes it difficult for many small and medium-sized entrepreneurs to assess their own financial position, demonstrate business viability, or facilitate credit financing. This situation is likely to lead Sri Lankan SMEs to make inappropriate financial decisions and end up with low performance and high failure rates. However, the strength of these factors motivates small and medium enterprises to maintain proper accounting records. Then, they can easily make the right decisions about their business operations, pay the appropriate taxes, and access credit facilities on the other hand. According to Amoako et al (2014), who stated that reasons why SMEs prepare final accounts ranking from major to least are profit determination, control purposes, bank loan requirement, tax purposes, and other reasons respectively are the rankings. Rathnasiri (2014), researched on financial reporting practices of SMEs in Sri Lanka. The researcher selected the target sample of 60 SMEs which are registered in the Ministry of Industry and Commerce. Since findings of the study showed that almost all the SMEs are not preparing the financial statements with the purpose of fulfilling that as a statutory obligation. The highest percentage representing 88 percent denotes that SMEs are preparing financial statements as a supportive for day to day operations. Around 67percent of SMEs prepare the financial statements with the intention to fulfill the financing purposes.
Thus most of the SMEs may not follow the proper formats of preparation of financial statements since they do not have any intention to meet the statutory obligations. But poorly prepared accounting information render most SMEs unable to evaluate their own financial situation, or to demonstrate viability of the business, and or to facilitate loan financing. This situation is having possible implications for Sri Lankan SMEs, to make improper financial decisions and ended up with low performance and high failure rate. Amoako (2013) researched on, what factors motivate others to maintain accounting records. Respondents agreed that the main purpose for keeping the records is "to keep track of receivables and payables". A larger percentage of respondents agree that it is important to monitor what is accounts receivable and accounts payable when running a business. According to Asaduzzaman (2016) found that there is a positive relationship between the Perception / motivation of the respondents and the financial performance of the small and medium scale entrepreneurs who keep accounts only for limited needs. majority of SMEs keep accounting records for the purpose of fulfilling statutory requirements, financing requirements (bank loan), day to day operating activities and for making decisions. Therefore business should keep accounting records to make appropriate business decisions not only considering external financing and tax purpose. Then business owners can make proper decisions to improve performance of the business. And these motivations improve their record keeping practices. Based on above literature, fourth hypothesis developed as,

H4: There is a significant effect of respondents' perception on financial performance of SMEs.

\section{Methodology}

\section{Conceptual Framework}

Figure 1: Conceptual Framework

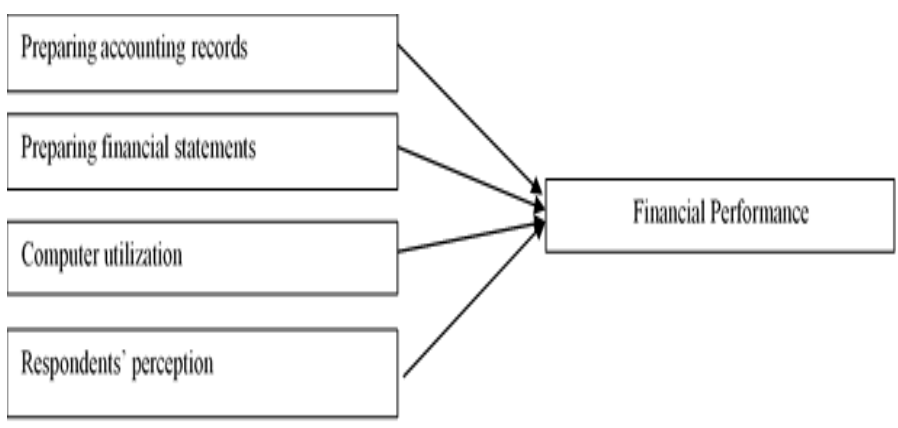

Source: Developed by Researcher (2021)

According to the figure 1, preparation of accounting records, preparation of financial statements, computer utilization and respondents' perception were identified as Independent variables of the study. Financial performance of SMEs was the Dependent variable. Financial performance depend on accounting record keeping practices considered in this study.

\section{Population, Sample and Data Collection}

The population of the study is 500 the SMEs registered in 
Chamber of Commerce, Anuradhapura district in the year 2021. 217 SMEs were selected as the sample according to (Sekaran, 2003) sample selection table. Data collected from SMEs through a structured questionnaire distributing to manufacturing, service and retail SMEs. Questionnaire consists with two parts. Part one reflect basic information and information about the enterprise and Part two reflect the information accounting record keeping practices \& financial performance. For this study, the researcher collects secondary data from research articles, newspapers, books, and the Internet.

\section{Research Model}

The independent variable is accounting records keeping practices, which is measured by using preparation of financial statements, preparation of accounting records, use of computers, and the perception of respondents, and the dependent variables is financial performance of SMEs. The algebraic expression of the regression model, which consists of a constant coefficient and an error term, takes the following form.

$$
\mathrm{Y}=\alpha+\beta 1 \mathrm{X} 1+\beta 2 \mathrm{X} 2+\beta 3 \mathrm{X} 3+\beta 4 \mathrm{X} 4+\mathrm{e}
$$

Where,

$\mathrm{Y}=$ Financial performance

$\mathrm{X} 1=$ Preparing accounting records

$\mathrm{X} 2=$ Preparing financial statements

$\mathrm{X} 3$ = Computer utilization

$\mathrm{X} 4=$ Respondents' perception

$\alpha=$ Constant term

$\beta 1$ to $\beta 4=$ Beta coefficients

$\mathrm{e}=$ Error term

\section{Data ANALYSIS AND Discussion OF RESUlts}

\section{Response Rate}

Sample size of the study was 217 SMEs operate in Anuradhapura District during the year 2021. 217 questionnaires were distributed among manufacturing, service and trade type of SMEs located in Anuradhapura area. However, due to the non-responsiveness and incompleteness 43 and 22 questionnaires were excluded respectively from the analysis. Therefore, the sample for the study was adjusted to 152. Accordingly, $70 \%$ of response rate was recorded for the present study.

\section{Reliability Test}

According to table 1 reliability test results at final data analyzing stage on each variables are higher than 0.7. Thus, internal consistency of the measures used in this study can be considered to be acceptable for accounting record keeping practices and SMEs performance measures.

Table 1: Results of the Reliability Test

\begin{tabular}{|c|c|c|}
\hline Variables & Cronbach's Alpha & $\begin{array}{c}\text { Number of } \\
\text { Questions }\end{array}$ \\
\hline PAR & 0.729 & 5 \\
\hline
\end{tabular}

\begin{tabular}{|c|l|l|}
\hline PFS & 0.794 & 5 \\
\hline CU & 0.770 & 5 \\
\hline RP & 0.719 & 5 \\
\hline FP & 0.875 & 5 \\
\hline
\end{tabular}

Source: SPSS Output (2021)

\section{Descriptive Statistics}

Table 2: Results of Descriptive Analysis

\begin{tabular}{|c|c|c|c|c|}
\hline & Minimum & Maximum & Mean & $\begin{array}{c}\text { Std. } \\
\text { Deviation }\end{array}$ \\
\hline FP & 2.40 & 4.60 & 3.46 & 0.53 \\
\hline PAR & 2.60 & 4.40 & 3.64 & 0.32 \\
\hline PFS & 2.60 & 4.40 & 3.60 & 0.42 \\
\hline CU & 2.40 & 4.40 & 3.27 & 0.36 \\
\hline RP & 2.40 & 4.00 & 3.41 & 0.32 \\
\hline
\end{tabular}

Source: SPSS Output (2021)

According to table 2, the mean value of the financial performance is 3.46. Standard deviation is 0.53 and it represents that mean value of the financial performance can be deviate by 0.53 . Among financial record keeping practices, preparing accounting records and preparing financial statements represents 3.64 and 3.60 mean values respectively. Mean values of computer utilization and respondents' perception is 3.27 and 3.41 respectively. All mean values are higher than the median value. It indicates that SMEs almost agree with accounting record keeping practices considered in this study.

\section{Correlation Analysis}

Table 3: Results of Correlation Analysis

\begin{tabular}{|c|c|c|c|c|c|c|}
\hline & & FP & PAR & PFS & CU & $\begin{array}{c}\text { RP } \\
\text { M }\end{array}$ \\
\hline \multirow{2}{*}{ FP } & Corr. & 1 & & & & \\
\hline & Sig. & & & & & \\
\hline \multirow{2}{*}{ PAR } & Corr. & $0.181^{* *}$ & 1 & & & \\
\hline & Sig. & 0.008 & & & & \\
\hline \multirow{2}{*}{ PFS } & Corr. & $0.527^{* *}$ & $0.381^{* *}$ & 1 & & \\
\hline & Sig. & 0.000 & 0.000 & & & \\
\hline \multirow{2}{*}{ CU } & Corr. & $0.465^{* *}$ & 0.110 & $0.696^{* *}$ & 1 & \\
\hline & Sig. & 0.000 & 0.106 & 0.000 & & \\
\hline \multirow{2}{*}{ RP } & Corr. & $0.466^{* *}$ & $0.206^{* *}$ & $0.715^{* *}$ & $0.687 * *$ & 1 \\
\hline & Sig. & 0.000 & 0.002 & 0.000 & 0.000 & \\
\hline
\end{tabular}

**. Correlation is significant at the 0.01 level (2-tailed).

Source: SPSS Output (2021)

According to table 3 , there is a significant positive relationship between accounting records keeping practices and financial performance at 0.01 significant levels. PAR has a positive 0.181 relationship with financial performance at 0.01 level of significant. PFS, CU and RPM have positive relationship with FP as $0.527,0.465$ and 0.466 respectively at 
the 0.01 level of significant.

\section{Multiple Regression Analysis}

Multiple regression analysis used to identify the effect of accounting record keeping practices on SMEs financial performance.

Table 4: Results of Regression Analysis

\begin{tabular}{|c|c|c|c|c|c|}
\hline & \multicolumn{2}{|c|}{$\begin{array}{c}\text { Unstandardized } \\
\text { Coefficients }\end{array}$} & $\begin{array}{c}\text { Standardized } \\
\text { Coefficients }\end{array}$ & $\mathrm{t}$ & Sig. \\
\hline & B & $\begin{array}{c}\text { Std. } \\
\text { Error }\end{array}$ & Beta & & \\
\hline (Constant) & 0.468 & 0.452 & 1.035 & 1.035 & 0.302 \\
\hline PAR & 0.022 & 0.104 & 0.211 & 0.211 & 0.833 \\
\hline PFS & 0.411 & 0.123 & 3.349 & 3.349 & 0.001 \\
\hline CU & 0.216 & 0.128 & 1.682 & 1.682 & 0.094 \\
\hline RPM & 0.215 & 0.148 & 1.451 & 1.451 & 0.148 \\
\hline F & \multicolumn{2}{|c|}{23.074} & R & \multicolumn{2}{c|}{$0.551^{\mathrm{a}}$} \\
\hline Sig & \multicolumn{2}{|c|}{0.000} & R Square & \multicolumn{2}{c|}{0.303} \\
\hline
\end{tabular}

Source: SPSS Output (2021)

According to table 4 , $\mathrm{R}$ squire value is 30.3 percent and it implies that 30.3 percent variation in the financial performance is explained by independent variables (Preparing accounting records, Preparing financial statements, Computer utilization, Respondents' perception) considered in this study. The $\mathrm{F}$ value in the ANOVA table tests whether the overall regression model is a good fit for the data. The table 4 shows that all the independent variables statistically and significantly predict the dependent variable as the $\mathrm{F}$ value is 23.074 and significant value is 0.000 which is lower than 0.05 levels of significance. So, it implies that regression model fits to the data. According to regression coefficients, there is a positive $(B=0.022)$ effect of PAR on Financial performance, but it is not significant (Sig. $=0.833$ ) at 0.05 level of significant. So, there is no significant effect of PAR on FP. Regression coefficient of PFS is positive 0.41.1 so, there is a there is a positive effect of PFS on Financial performance. On the other hand the significant value is 0.001 , it is significant at 0.05 level of significant. Tis finding is confirmed by Auken \& Carrahe (2013), Madurapperuma et al (2016), they confirm that most SMEs prepare a complete set of financial statements with preparing financial statement at all. So, there is a positive significant effect of PFS on FP at 0.05 level of significant. CU has a positive $(B=0.216)$ effect on FP, but it is not significant ( $\mathrm{Sig}=0.094)$. RPM has a positive $(\mathrm{B}=0.215)$ effect on FP but it is not significant (Sig: 0.148) at 0.05 level of significant.

\section{CONCLUSION}

The study was carried out to investigate the effect of accounting record keeping practices on financial performance of SMEs. Preparing accounting records, preparing financial statements, computer utilization, and respondents' perception were identified as independent variables and financial performance was identified as the dependent variable. The population of the study was 500 SMEs registered in Chamber of Commerce, Anuradhapura and 217 selected as the sample, but final sample was 152 SMEs operating in Anuradhapura District. Data were collected from SMEs using a standard questionnaire and collected data was analyzed using SPSS software package. Research hypotheses were tested based on regression results.

Table 5: Testing of Hypotheses

\begin{tabular}{|c|c|c|}
\hline Hypotheses & $\begin{array}{c}\text { Regression } \\
\text { Results }\end{array}$ & $\begin{array}{c}\text { Accepted/Rej } \\
\text { ected }\end{array}$ \\
\hline $\begin{array}{c}\text { H1: There is a significant effect of } \\
\text { preparing accounting records on } \\
\text { financial performance of SMEs. }\end{array}$ & $\begin{array}{c}\mathrm{B}=0.022 \\
\mathrm{Sig}=0.833\end{array}$ & Rejected \\
\hline $\begin{array}{c}\text { H2: There is a significant effect of } \\
\text { preparing financial statements on } \\
\text { financial performance of SMEs. }\end{array}$ & $\begin{array}{c}\mathrm{B}=0.411 \\
\mathrm{Sig}=0.001\end{array}$ & Accepted \\
\hline $\begin{array}{c}\text { H3: There is a significant effect of } \\
\text { computer utilization on financial } \\
\text { performance of SMEs. }\end{array}$ & $\mathrm{B}=0.216$ & Rejected \\
\hline $\begin{array}{c}\text { H4: There is a significant effect of } \\
\text { respondents' perception on financial } \\
\text { performance of SMEs. }\end{array}$ & $\mathrm{B}=0.094$ & $\mathrm{Sig}=0.148$ \\
\hline
\end{tabular}

According to the table five hypotheses were tested based on regression results and rejected all hypotheses except hypotheses number two. According to the findings, there is a significant effect of preparing financial statements on financial performance of SMEs. Other accounting record keeping practices such as preparing accounting records, computer utilization and respondents' perception has a positive effect on financial performance but they have not significant effect on financial performance.

\section{RECOMMENDATION AND SUGGESTIONS FOR FUTURE RESEARCH}

This study examines the effect of accounting record keeping practices on financial performance of SMEs in Sri Lanka. According to research findings, it was identified there is a significant positive relationship between preparing financial statements on financial performance. So, Sri Lankan SMEs should keep more attention on preparing financial statements when they are engaging in day to day operating activities. So, SMEs owners, managers and other parties engaging in accounting activities should pay their attention on establishing and practicing proper record keeping practices in the business. In addition to preparing financial statements other variable shows a positive relationship with financial performance of SMEs. So, SMEs should have thorough knowledge regarding what are the account record keeping practices available, how to adopt them in to the SME, how to practice those practices. So, SME owners, managers, accountants, cash officers and other relevant parties should gather knowledge relating to accounting record keeping practices in order to enhance their business performance. Moreover, the study recommends that regulatory authorities like Industry Development Board, 
Chamber of Commerce, Department of Small Industries, Ministry of Industry, Tourism and Investment Promotion, National Enterprise Development Authority...etc should encourage SMEs to setup a sound accounting systems by giving knowledge on relevant practices organizing workshops, seminars, appointing knowledge disseminating groups...etc, on accounting record keeping practices for a better performance of SMEs. In addition to that Sri Lankan government should take necessary actions for enhancing the adaptability accounting recordkeeping practices in SMEs introducing new standards, specifications, laws, rules and regulations. Finally, researcher recommends that Sri Lankan SMEs should get the employment of accounting experts to assist the practices in order to uplift the financial performance of SMEs.

\section{REFERENCES}

[1] Amoako, G. (2013). Accounting Practices of SMEs: A Case Study of Kumasi Metropolis in Ghana. International Journal of Business and Management Vol. 8, 73-83.

[2] Asaduzzaman, M. D. (2016). Accounting and Financial Reporting Practices of SMEs: Bangladesh Perspective. Malaysian Journal of Business and Economics Vol. 3, No. 1, 2016, 57 - 67 .

[3] Bandara, R., \& Rathnasiri, U. (2016, September). The Working Capital Management Practices of Small and Medium Enterprises (SMEs) in Sri Lanka. ICME 2016, Faculty of Management and Finance, University of Ruhuna.

[4] Bandara, R., \& Rathnasiri, U. (2016, September). The Working Capital Management Practices of Small and Medium Enterprises (SMEs) in Sri Lanka. ICME 2016, Faculty of Management and Finance, University of Ruhuna.

[5] CA Sri lanka. (2014). CA Sri Lanka focuses on enhancing financial structure of SMEs. the island e-pepar.

[6] Emmanuel, M., Hayford , A., Collins, M., \& Christian , O. (2014). Assessing Financial Reporting Practices Among Small Scale Enterprises in Kumasi Metropolitan Assembly. European.

[7] Esselaar, S., \& Stork, C. (2007). ICT Usage and Its Impact on Profitability of SMEs in 13 African Countries. journal African universities and research institutions working on ICT Volume 4, Number 1, Fall 2007,, 87-100.

[8] Ismail, N. A., \& King , M. (2007). Factors influencing the alignment of accounting information systems in small and medium sized Malaysian manufacturing firms. Journal of Information Systems and Small Business 2007, vol. 1, no. 1- 2, , 1-20.

[9] Jayasekara , J., \& Thilakarathna, A. (2013). Government Policy and Strategy for SME Development. The Fourth IMF-Japan HighLevel Tax Conference For Asian Countries in Tokyo April 2-4, 2013.

[10] Jennifer, K., \& Deninis, O. (2015). Financial Management Practices on Growth of Small and Medium Enterprises: A case of Manufacturing Enterprises in Nairobi County, Kenya. AIOSR Journal of Business and Management, 17, 24- 35.

[11] Kofi, M. E., HayfordAdjei, Collins, M., \& Christian, A. O. (2014). Assessing financial reporting practices among small scale assessing financial reporting practices among small scale. European Journal of Business and Social Sciences, Vol. 2,No.10, 81-96.

[12] Ludmila, K., Lubor, H., \& Dimitris, K. (2017). The Effect of Business Environment and Entrepreneurs' Gender on Perception of Financial Risk in The Smes Sector. Journal of Competitiveness Vol. 9, Issue 1, pp. 36 - 50, March 2017.

[13] Maseko, N., \& Manyani , O. (2011). Accounting practices of SMEs in Zimbabwe: Aninvestigative study of record keeping for performance measurement (A case study of Bindura). Journal of Accounting and Taxation Vol. 3(8), 171- 181.
[14] Karunananda, U., \& Jayamaha, A. (2011). Associations of Financial Practices and Performance of Small and Medium -sized Enterprises in Sri Lanka. Journal of Management 1(1) 2011, 1-21.

[15] Liao , T., \& Rice, J. (2010). Innovation investments, market engagement and financial performance:A study among Australian manufacturing SMEs. T.-S. Liao, J. Rice / Research Policy 39 (2010), 117-125.

[16] Madurapperuma, M. W., Thilakerathne, P. M., \& Manawadu, I. N. (2016). Accounting Record Keeping Practices in Small and Medium Sized Enterprise's (SME's) in Sri Lanka. Journal of Finance and Accounting, 188- 192.

[17] Rathnasiri, U. (2014). Financial reporting practices of small and medium enterprises (smes) in sri lanka. International Journal of Academic Research in Business and Social Sciences 4, 73-83.

[18] Raymond , A. E., Emmanuel, E., \& Moses, C. O. (2014). The Relevance of Accounting Records in Small Scale Business: The Nigerian Experience. International Journal of Academic Research in Business and Social Sciences December 2014, Vol. 4, No. 12, 69-82.

[19] Sapiei, S., Mustapha, M., \& Abdullah, M. (2016). SMEs' tax compliance costs and IT adoption: the case of a value-added tax. International Journal of Accounting Information Systems Volume 23, December 2016.

[20] Yousef, B., \& Smirat, A. (2013). The Use of Accounting Information by Small and Medium Enterprises in South District of Jordan, ( An empirical study). Research Journal of Finance and Accounting (Online) Vol.4, No.6, 2013, 169- 175 